\title{
Pengaruh Metode Drill Dan Practice (D\&P) Terhadap Peningkatan Kemampuan Berpikir Kreatif Siswa Sekolah Dasar Ditinjau Dari Kemampuan Awal Matematis
}

\author{
Johannis Takaria \\ Program Studi PGSD-FKIP Unpatti Ambon \\ Johannistakaria007@gmail.com \\ Yuyun Sahusiwa \\ Program Studi PGSD-FKIP Unpatti Ambon \\ YuyunS@yahoo.com
}

\begin{abstract}
Abstact
Mathematical creative thinking skill is important for elementary school students to have so they can be actively involve in solving challenging mathematical problems. Related to this, the purpose of the study is to determine the effect of Drill and Practice (D\&P) methods on improving student mathematical creative thinking abilities in terms of their initial Prior-Ability on Mathematics (PAM). The study used a Quasi Experiment method with the type of One Group Pre test-Post test Design and involved 22 students as a research sample that were selected pro positively. To analyze the increase in mathematical creative thinking abilities used $N$ gain. The result showed that there was an influence of the D\&P method on improving student mathematical creative thinking abilities in terms of PAM. Further tests using the Post Hoc Test showed that high PAM level $><$ moderate there was no difference, while high PAM $><$ low and moderate $><$ low there was a difference. Each PAM level achieved an increase in the medium category. The increase is due to the effectiveness of the D\&P method. The D\&P method can trigger an increase in student creative thinking skills because students Practice working on questions and Practice on contextual problems. This process allows students to explore their creative thinking abilities
\end{abstract}

Keyword: Mathematical Creative Thinking Ability. Drill and Practice $(D \& P), P A M$
Abstrak
Kemampuan berpikir kreatif matematis penting untuk dimiliki siswa Sekolah Dasar sehingga mereka dapat terlibat aktif dalam menyelesaikan permasalahan matematika yang menantang. Terkait hal tersebut maka tujuan penelitian adalah mengetahui pengaruh metode Drill dan Practice (D\&P) terhadap peningkatan kemampuan berpikir kreatif matematis siswa yang tinjau dari kemampuan awal matematis (KAM). Penelitian menggunakan metode Quasi Eksperiment dengan tipe One Group Pretest- Posttest Desaign dan melibatkan 22 siswa sebagai sampel penelitian yang dipilih secara proposive. Untuk menganalisis peningkatan kemampuan berpikir kreatif matematis digunakan $N$-gain. Hasil penelitian menunjukan bahwa terdapat pengaruh metode D\&P terhadap peningkatan kemampuan berpikir kreatif matematis siswa ditinjau dari KAM. Uji lanjut menggunakan Post Hoc Test menunjukan bahwa KAM 
level tinggi $><$ sedang tidak terdapat perbedaan, sedangkan KAM tinggi $><$ rendah dan sedang $><$ rendah terdapat perbedaan. Setiap level KAM mencapai peningkatan dalam kategori sedang. Peningkatan dikarenakan efektivitas metode D\&P. Metode D\&P dapat memicu peningkatan kemampuan berpikir kreatif siswa, karena siswa berlatih mengerjakan soal-soal dan mempraktekan terhadap permasalahan kontekstual. Proses ini membuat siswa dapat mengeksplorasi kemampuan berpikir kreatif mereka

Kata Kunci: Kemampuan Berpikir Kreatif Matematis. Drill dan Practice (D\&P), KAM

\section{Pendahuluan}

Kemampuan berpikir kreatif penting untuk dimiliki setiap siswa dalam pembelajaran. Siswa kreatif dapat mengkonstruksi berbagai ide kreatif dalam pemecahan masalah matematika. Runco (1993; Mann, 2006) kreaktivitas merupakan suatu konstruk beragam dan melibatkan pemikiran konvergen, penemuan, pemecahan masalah, ekspresi diri, motivasi intrinsik, sikap mempertanyakan, dan kepercayaan diri.

Joong Kim, et al (2019) kreativitas memiliki peran penting dalam pendidikan matematika sekolah, karena dapat menumbuhkan pemikiran kreatif dan digunakan sebagai alat pedagogis untuk mengembangkan sikap positif dalam pembelajaran matematika. Temuan Hana dan Hamada (2017) bahwa kreaktivitas penting dalam mengembangkan keterampilan intelektual dan prestasi akademik siswa. Firdauisi dkk (2018) kemampuan berpikir kreatif matematis sangat diperlukan untuk menyelesaikan soal yang rumit karena dengan mengembangkan kemampuan siswa pada aspek berpikir kreatif maka siswa mampu menyelesaikan permasalahan matematika dengan berbagai cara.

Pentingnya kemampuan berpikir kreatif matematis siswa dalam pembelajaran berbanding terbalik dengan permasalahan berpikir kreatif matematis siswa. Permasalahan siswa dalam upaya pengembangan kemampuan berpikir kreatif disebabkan guru tidak optimal dalam mengeksplorasi kemampuan berpikir siswa. Gregoire (2016) guru hendaknya tidak secara eksklusif menekankan pada jawaban yang benar, prosedur yang tepat, kecepatan, dan ketepatan, namun guru harus memicu pengembangan pemikiran orisinal, memberikan peluang untuk mencari, mengeksplorasi, membuat dugaan, menguji, menyangkal, mengadaptasi strategi, menyusun rencana, menyimpulkan, bernalar, dan membuat kesimpulan. Nadjafikhah et al (2012; Gregoire, 2016) para siswa harus didorong untuk mengambil risiko, melakukan kesalahan, dan diberikan kesempatan untuk menyelidiki jalur alternatif dari suatu permasalahan.

Teridentifikasi melalui studi awal penelitian bahwa; 1) siswa perlu dilatih menyelesaikan soal-soal yang memuat indikator kemampuan berpikir kreatif sehingga dapat memicu peningkatan kemampuan berpikir kreatif siswa; 2) terkait dengan materi hitung bilangan bulat, ditemukan banyak siswa belum kreatif menggunakan garis bilangan secara benar; 3) pemahaman terhadap penguasaan sifatsifat distributif perkalian terhadap penjumlahan perlu ditingkatkan; 4) perlunya penggunaan modul instruksional sebagai penuntun praktek siswa dalam menyelesaikan soal-soal berpikir kreatif; dan 5) kurang tepatnya pemilihan metode pembelajaran kreatif dalam upaya peningkatan kemampuan berpikir kreatif matematis siswa.

Permasalahan kemampuan berpikir kreatif matematis siswa Sekolah Dasr perlu dicari solusinya, karena kemampuan berpikir kreatif penting bagi siswa dalam pembelajaran dan merupakan konstruk yang terimplementasi melalui banyak ide yang dimiliki siswa dalam menemukan berbagai cara kebaruan dari suatu pemecahan 
masalah. Untuk mengukur kemampuan berpikir kreatif maka Torrance mengembangkan instrumen tes yang sudah divalidasi untuk menilai pemikiran kreatif siswa yang dikenal dengan The Torrance Tests of Creative Thinking (TTCT) (Torrance, 1966; 1974; 1988; Silver, 1997). Silver (1997) Tiga komponen utama kreativitas dalam TTCT adalah kelancaran (fluency), fleksibilitas (flexibility) dan kebaruan (originality).

Fluency adalah kemampuan untuk menghasilkan berbagai solusi berbeda dari suatu permasalahan dan flexibility adalah kemampuan untuk menghasilkan berbagai ide berbeda dari suatu permasalahan, sedangkan Originality adalah kemampuan untuk menciptakan ide-ide baru dari hasil identifikasi suatu permasalahan (Vale dan Barbosa, 2015). Dalam konteks sosiakultural dan sejarah tertentu untuk memenuhi batasan tugas atau kebermaknaan, maka kreativitas umumnya merupakan suatu kombinasi antara originality, kebaruan, atau kebaruan dan kegunaannya, (Amabile, 1996; Sternberg \& Lubart, 1999; Kaufman \& Beghetto, 2009; Plucker, et al, 2004; Simonton, 2012; Gajda, et al, 2016).

Berdasarkan hasil identifikasi permasalahan siswa, maka perlu diterapkan metode D\&P yang diharapkan dapat meningkatkan kemampuan berpikir kreatif siswa sehingga berdampak pada ketercapaian hasil belajar matematika. Pada sisi lain bentuk soal yang digunakan dalam meningkatkan kreaktivitas siswa hendaknya berbentuk uraian bervariasi yang sifatnya non rutin mencakup penerapan dan analisa sehingga siswa dapat mengeksplorasi ide-ide kreatif.

Pembelajaran matematika yang melibatkan proses D\&P dapat memicu peningkatan kemampuan berpikir kreatif siswa. Dengan sering berlatih mengerjakan soal-soal membuat siswa terbiasa memahami pola atau bentuk soal yang diujikan dan dapat mempertajam kemampuan berpikir kreatif mereka. Sam Lim, et al (2012) D\&P didefinisikan sebagai metode pengajaran yang ditandai dengan pengulangan konsep, contoh, dan masalah praktik yang sistematis. D\&P adalah latihan yang disiplin dan berulang-ulang, digunakan sebagai sarana untuk mengajar dan menyempurnakan keterampilan atau prosedur. Ericsson (2016; Lehtinen, et al, 2017) salah satu karakteristik latihan yang dilakukan secara sengaja berfokus pada memodifikasi dan meningkatkan keterampilan yang diperoleh sebelumnya dan membangun keterampilan ke arah yang lebih baik dari keterampilan yang sudah dimiliki.

D\&P berkontribusi dalam pengembangan sikap dan kemampuan siswa. Alessi \& Trollip (1991; Gee \& Umar, 2014) D\&P multimedia dikembangkan melalui penggunaan panduan desain model instruksional. (Hsu \& Maan Sheu, 2008) D\&P dilakukan dengan cara memberikan latihan berulang dengan pemberian umpan balik dan materi disajikan dengan cepat. Gee \& Umar (2014) para peneliti telah menemukan manfaat D\&P dalam pembelajaran, misalnya Drowns \& Robert (1985) menemukan bahwa D\&P secara langsung bermanfaat bagi siswa dalam pembelajaran, dan secara tidak langsung memotivasi mereka untuk belajar.

Metode D\&P membantu siswa dalam mengkonstruksi ide-ide kreatif melalui schaffolding dari guru. Siswa dilatih menyelesaikan soal non rutin dan terimplementasi melalui praktek yang dilakukan secara kontinu, karena dengan praktek materi yang dipelajari dapat dipahami secara mendalam dan bermakna. D\&P dilakukan dengan cara: 1) pemberian soal untuk dilatih secara kontinu dengan bantuan modul pembelajaran matematika yang didesain berorientasi masalah kontekstual; 2) siswa dilatih membuat garis bilangan dari soal yang diberikan; 3) siswa diberikan praktek implementasi operasi hitung bilangan bulat secara kontekstual; dan 4) siswa mengkonstruksi penyelesaian operasi bilangan bulat dengan kreaktivitas melalui ide-ide yang dimiliki.

Kemampuan berpikir kreatif siswa perlu ditunjang dengan kemampuan awal matematis (KAM). Siswa dengan KAM yang baik dapat terlibat aktif dalam menghadapi dan menyelesaikan berbagai permasalahan yang menantang (Takaria \& 
Talakua, 2018). Kemampuan awal (Prior-knowledge) dapat digunakan untuk mengidentifikasi siswa terkait studi mereka untuk; 1) menemukan gambaran dalam memulai pembelajaran; 2) pemberian umpan balik kepada siswa; 3) menjembatani kesenjangan antara harapan instruktur dan kemampuan dasar siswa; dan 4) dapat mengelompokkan siswa sesuai dengan kemampuan mereka (Hailikari et al, 2008; Takaria \& Talakua, 2018). Purwaningrum \& Sumardi (2016) KAM berpengaruh terhadap hasil belajar matematika. Razak (2017) menjelaskan bahwa terdapat hubungan yang kuat antara kemampuan awal siswa dengan kemampuan berpikir kritis. Hubungan ini tentunya dapat memicu kemampuan berpikir kreatif siswa dalam menyelesaikan soal matematika yang menantang.

Mengacu pada uraian yang dikemukakan dan hasil identifikasi permasalahan maka tujuan penelitian ini adalah untuk mengetahui pengaruh metode drill dan practice (D\&P) terhadap peningkatan kemampuan berpikir kreatif matematis siswa Sekolah Dasar yang tinjau dari KAM.

\section{Metode}

Metode yang digunakan dalam penelitian ini adalah Quasi Eksperiment dengan tipe One Group Pretest-Posttest Design. Tujuannya untuk mengetahui pengaruh peningkatan kemampuan berpikir kreatif matematis siswa melalui penggunaan metode pembelajaran D\&P ditinjau dari KAM.

\section{Partisipan}

Sampel penelitian melibatkan 22 siswa kelas V SD Inpres 48 Ambon. Pemilihan lokasi penelitian dikarenakan SD Inpres 28 Ambon merupakan sekolah mitra dari Prodi PGSD Unpatti sehingga berdasarkan hasil observasi pembelajaran, khususnya kualitas pelajaran matematika perlu ditingkatkan pada aspek kemampuan berpikir kreatif matematis siswa. Tabel 1 menyajikan desain penelitian

\section{Tabel 1. Desain Penelitian}

\begin{tabular}{cc}
\hline KAM & Metode D\&P \\
\hline Tinggi $\left(\mathrm{K}_{1}\right)$ & $\mathrm{K}_{1} \mathrm{DP}_{1}$ \\
\hline Sedang $\left(\mathrm{K}_{2}\right)$ & $\mathrm{K}_{2} \mathrm{DP}_{1}$ \\
\hline Rendah $\left(\mathrm{K}_{3}\right)$ & $\mathrm{K}_{3} \mathrm{DP}_{1}$ \\
\hline
\end{tabular}

Keterangan:

Ki: $\quad$ siswa yang memiliki KAM pada level ke-i, untuk (i=1, 2, 3), dengan 1= tinggi, $2=$ sedang, 3 = rendah

DPj: $\quad$ siswa yang mendapatkan pembelajaran dengan metode $k e-j$, untuk $\mathrm{j}=1$

KiDPj: siswa yang memiliki KAM level ke-i, yang mendapatkan pembelajaran dengan metode ke-j.

\section{Instrumen}

Instrumen yang digunakan untuk melihat pengaruh metode D\&P terhadap peningkatan kreativitas siswa adalah: 1) tes kreaktivitas; untuk mengukur kreaktivitas awal (pretest) dan tes akhir (posttest) ; 2) Lembar observasi; lembar observasi digunakan untuk mengamati aktifitas guru dan aktifitas siswa selama proses pembelajaran berlangsung.

\section{Teknik Analisis Data}

Analisis data untuk melihat pengaruh metode D\&P terhadap peningkatan kemampuan berpikir kreatif matematis siswa menggunakan One Way Anova. Data pretest dan posttest sebelum dianalisis perlu diformulasikan hipotesis penelitian dan selanjutnya dilakukan uji asumsi yaitu, uji normalitas dan homogenitas. Uji normalitas bertujuan untuk menentukan apakah data tes kreaktivitas berdistribusi 
normal atau tidak. Uji normalitas menggunakan Kolmogorov-Smirnov dengan kriteria normal jika nilai sig. > 0,05. Sedangkan uji homogenitas menggunakan uji levene berdasarkan pada besaran probabilitas atau nilai signifikan. Data dikatakan memenuhi asumsi homogen jika nilai sig. $>0,05$. Selanjutnya dilakukan uji perebedaan kreaktivitas berdasarkan KAM dan keseluruhan siswa dengan menggunakan paired sample t-test serta menganalisis pengaruh dengan menggunakan Anova. Proses input dan pengolahan data mnggunakan program statistik SPSS 22.0 For Windows.

Untuk menganalisis peningkatan kemampuan berpikir kreatif matematis siswa, digunakan $N$-gain (Hake, 1998 ;Takaria, 2018) :

$$
N-\text { gain }=\frac{\text { posttest score }- \text { pretest score }}{\text { maximum possible score }- \text { pretest score }}
$$

Hasil perhitungan (N-gain) yang diperoleh, dikonfirmasikan dengan kriteria gain ternormalisasi pada Tabel 2.

Tabel 2. Kriteria N-gain

\begin{tabular}{cc}
\hline $\mathbf{N}-$ gain $(<\mathbf{g}>\mathbf{)}$ & Klasifikasi \\
\hline $\mathrm{g} \geq 0,70$ & Tinggi \\
\hline $0,30 \leq \mathrm{g}<0,70$ & Sedang \\
\hline $\mathrm{g}<0,30$ & Rendah \\
\hline
\end{tabular}

Untuk mengukur tingkatan kreativitas siswa maka digunakan skor tingkatan kreaktivitas. Siswono (2008) membagi kreativitas menjadi 5 tingkatan yaitu, tingkat 4 (sangat kreatif), tingkat 3 (kreatif), tingkat 2 (cukup kreatif), tingkat 1 (kurang kreatif), dan tingkat 0 (tidak kreatif), dimana tingkatan kreaktivitas dan karakteristiknya disajikan dalam Tabel 3

Tabel 3. Tingkat Kreaktivitas dan Karakteristiknya

\begin{tabular}{lll}
\hline \multicolumn{1}{c}{ Tingkatan } & \multicolumn{3}{c}{ Karakteristik } \\
\hline Tingkat 4 (Sangat Kreatif) & $\begin{array}{l}\text { Siswa mampu menunjukan kefasihan, } \\
\text { fleksibilitas, dan kebaruan atau kebaruan dan } \\
\text { fleksibilitas dalam pemecahan masalah }\end{array}$ \\
\hline Tingkat 3 (Kreatif) & $\begin{array}{l}\text { Siswa mampu menunjukan kefasihan dan } \\
\text { kebaruan atau kefasihan dan fleksibilitas dalam } \\
\text { pemecahan masalah }\end{array}$ \\
\hline Tingkat 2 (Cukup Kreatif) & $\begin{array}{l}\text { Siswa mampu menunjukan kebaruan atau } \\
\text { fleksibilitas dalam pemecahan masalah }\end{array}$ \\
\hline Tingkat 1 (Kurang Kreatif & $\begin{array}{l}\text { Siswa mampu menunjukan kefasihan dalam } \\
\text { pemecahan masalah }\end{array}$ \\
\hline Tingkat 0 (Tidak Kreatif) & $\begin{array}{l}\text { Siswa tidak mampu menunjukan ketiga aspek } \\
\text { indikator dalam pemecahan masalah }\end{array}$ \\
\hline
\end{tabular}

Hasil

Data hasil penelitian dikumpulkan melalui skor pretest dan posttest dalam mengukur kreaktivitas siswa kelas V SD Inpres 48 Ambon. Pretest dilakukan sebelum diterapkan metode pembelajaran drill dan practice. Setelah diberikan perlakukan maka selanjutnya dilakukan posttest. Tabel 4 menyajikan diskripsi ukuran parameter statistik kreaktivitas ditinjau dari KAM siswa.

Tabel 4. Parameter Statistik Kreaktivitas Siswa Ditinjau dari KAM 
Takaria, J., Sahusiwa, Y.

\begin{tabular}{cccccc}
\hline \multirow{2}{*}{ Level KAM } & \multicolumn{5}{c}{ Pretest } \\
\cline { 2 - 6 } & $n$ & Mean & Minimum & Maximum & Std Deviation \\
\hline Rendah & 5 & 26,80 & 26,00 & 28,00 & 1,09 \\
\hline Sedang & 12 & 33,00 & 26,00 & 40,00 & 3,76 \\
\hline Tinggi & 5 & 39,60 & 38,00 & 42,00 & 1,67 \\
\hline & $n$ & Mean & Minimum & Maximum & Std Deviation \\
\hline Rendah & 5 & 63,00 & 55,00 & 70,00 & 5,70 \\
\hline Sedang & 12 & 72,50 & 65,00 & 85,00 & 5,43 \\
\hline Tinggi & 5 & 80,00 & 75,00 & 85,00 & 3,53 \\
\hline
\end{tabular}

Tabel 4 memperlihatkan pretest dan posttest pada materi operasi bilangan bulat, kelompok KAM level tinggi memiliki rerata lebih tinggi dari kelompok level sedang dan rendah. Nilai maximum pretest dan posttest KAM tinggi juga lebih besar dari level sedang dan rendah, sedangkan keberagaman hasil pretest kreaktivitas level sedang lebih bervariasi dari level rendah dan tinggi. Untuk skor posttest mahasiswa level rendah dan sedang memiliki varians skor tes kreaktivitas lebih tinggi dari mahasiswa KAM tinggi.

Untuk melihat pengaruh metode drill dan practice terhadap peningkatan kreaktivitas siswa ditinjau dari level KAM, maka dilakukan pengujian dengan menggunakan One Way Anova. Sebelum dilakukan pengujian maka langkah awal yang dilakukan adalah merumuskan hipotesis penelitian sebagai berikut:

Hipotesis

Ho: Tidak ada pengaruh metode D\&P terhadap peningkatan kemampuan berpikir kreatif matematis siswa

$\mathrm{H}_{1}$ : Ada pengaruh metode $\mathrm{D} \& \mathrm{P}$ terhadap peningkatan kemampuan berpikir kreatif matematis siswa

Sebagai syarat dalam uji statistik inferensial, maka perlu dilakukan uji asumsi normalitas dan homogenitas. Tabel 5 menyajikan hasil pengujian asumsi.

Tabel 5. Uji Normalitas dan Homogenitas N-gain

\begin{tabular}{|c|c|c|c|c|}
\hline \multicolumn{5}{|c|}{ Normalitas } \\
\hline \multirow{6}{*}{$N$-gain } & \multirow[b]{2}{*}{ KAM } & \multicolumn{2}{|c|}{ Kolmogorov-Smirnov } & \multirow[b]{2}{*}{ Keputusan } \\
\hline & & Test Statistic & $\begin{array}{c}\text { Sig. } \\
\text { (2-tailed) }\end{array}$ & \\
\hline & Rendah & 0,188 & 0,200 & Normal \\
\hline & Sedang & 0,203 & 0,184 & Normal \\
\hline & Tinggi & 0,300 & 0,161 & Normal \\
\hline & Keseluruhan & 0,086 & 0,200 & \\
\hline \multicolumn{5}{|c|}{ Homogenitas } \\
\hline \multirow[t]{2}{*}{$N$-gain } & \multirow{2}{*}{$\begin{array}{c}\text { KAM } \\
\text { Gabungan }\end{array}$} & Levene Statistic & Sig. & Keputusan \\
\hline & & 2,905 & 0,104 & Homogen \\
\hline
\end{tabular}

Hasil pengujian asumsi menunjukan $N$-gain $\mathrm{KAM}$ rendah, sedang, dan tinggi berdistribusi normal karena nilai Sig.(2-tailed) > 0,05. Untuk pengujian homogenitas data terlihat bahwa KAM gabungan dengan menggunakan Levene statistik nilai Sig. $(0,104)>0,05$, artinya data nilai $N$-gain homogen. Syarat pengujian normalitas dan homogenitas terpenuhi maka digunakan uji parametrik dengan pengujian menggunakan One Way Anova.

Berdasarkan hasil pengolahan data diperoleh nilai F sebesar 8,48 dengan Sig sebesar $0,002<0,05$ sehingga hipotesis diterima, artinya terdapat pengaruh metode D\&P terhadap peningkatan kemampuan berpikir kreatif matematis siswa. Selanjutnya 
dilakukan uji lanjut menggunakan Post Hoc Test dalam melihat level mana saja yang berbeda secara signifikan. Tabel 6 menyajikan uji perbedaan berdasarkan KAM.

Tabel 6. Uji Perbedaan Berdasarkan KAM

\begin{tabular}{cccc}
\hline Level KAM & $\begin{array}{c}\text { Mean } \\
\text { Deference }\end{array}$ & Sig & Keputusan \\
\hline Tinggi $><$ Sedang & 0,079 & 0,098 & Tidak Berbeda \\
\hline Tinggi $><$ Rendah & $0,176^{*}$ & 0,002 & Berbeda \\
\hline Sedang $><$ Rendah & $0,968^{*}$ & 0,037 & Berbeda \\
\hline
\end{tabular}

Tabel 6 memperlihatkan bahwa untuk tes kreaktivitas level tinggi dan sedang tidak ada perbedaan yang ditunjukan dengan nilai Sig. $(0,098)>0,05$. Untuk level tinggi dan rendah, serta sedang dan rendah dengan nilai sig. $(0,002$ dan 0,037$)<0,05$ maka terdapat perbedaan atau dengan melihat tanda bintang pada nilai Mean Deference. Hal ini mengindikasikan ada perbedaan peningkatan kreaktivitas matematis siswa setelah mendapatkan pembelajaran dengan metode drill dan practice.

Untuk menganalisis peningkatan kreaktivitas matematis siswa berdasarkan level kemampuan maka digunakan $N$-gain. Gambar 1 menyajikan rerata presentase kategori peningkatan kreaktivitas berdasarkan KAM.

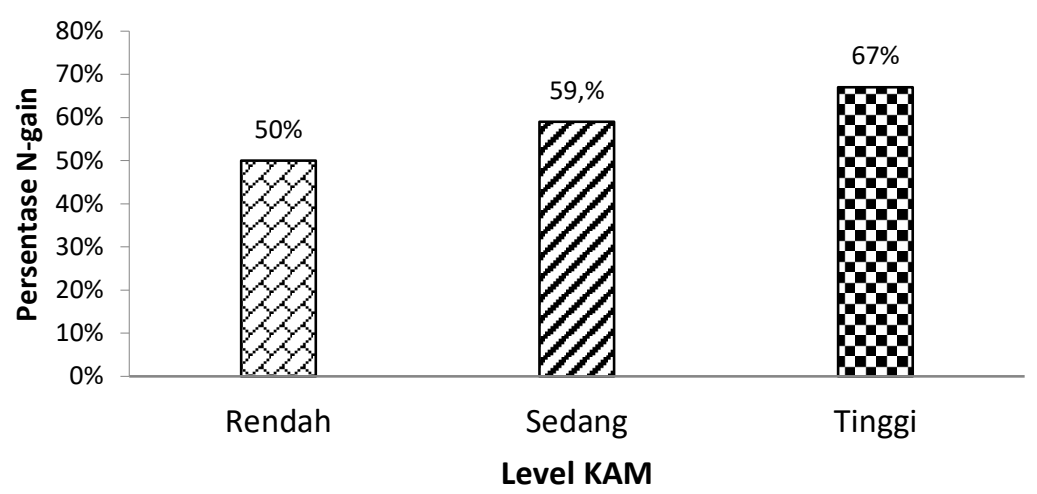

\section{Gambar 1. Persentase Peningkatan Kreaktivitas Siswa Berdasarkan KAM}

Persentasi peningkatan kemampuan berpikir kreatif matematis siswa berdasarkan KAM pada Gambar 1 memperlihatkan bahwa siswa dengan KAM rendah (50\%), sedang (59\%), dan tinggi (67\%) mencapai peningkatan kemampuan kreaktivitas dalam kategori sedang. Peningkatan ini dikarenakan efektifnya penggunaan metode D\&P dalam pembelajaran.

Untuk mengukur tingkat kreaktivitas siswa maka digunakan tes kreaktivitas yang sudah diuji validitas dan reliabelitasnya. Tingkatan hasil tes kreaktivitas disajikan pada Tabel 7.

Tabel 7. Tingkat Kreaktivitas Siswa

\begin{tabular}{cccc}
\hline No & Tingkat Kreaktivitas & Persentase (\%) & Kategori \\
\hline 1 & Tingkat-4 & 18,18 & Sangat Kreatif \\
\hline 2 & Tingkat-3 & 54,55 & Kreatif \\
\hline 3 & Tingkat-2 & 22,72 & Cukup Kreatif \\
\hline 4 & Tingkat-1 & 4,55 & Kurang Kreatif \\
\hline
\end{tabular}


Tingkat kreaktivitas siswa SD dalam menyelesaikan soal operasi hitung bilangan pada Tabel 7 memperlihatkan bahwa $18,18 \%$ sangat kreatif, $54,55 \%$ pada tingkatan kreatif, $22,72 \%$ cukup kreatif, dan 4,55\% siswa kurang kreatif. Hasil ini menunjukan bahwa mayoritas siswa berada pada kategori kreatif. Kreaktivitas siswa dipengaruhi oleh metode pembelajaran yang digunakan. Metode D\&P efektif karena siswa dilatih menyelesaikan soal dan melakukan praktek dengan media pembelajaran kontekstual berbantuan modul pembelajaran.

Kemampuan berpikir kreatif ditunjukan dengan hasil kerja siswa, dimana siswa dapat menunjukan fluency, flexibility dan originality. Gambar 2 menyajikan salah satu hasil kerja siswa dalam mengukur aspek fleksibilitas

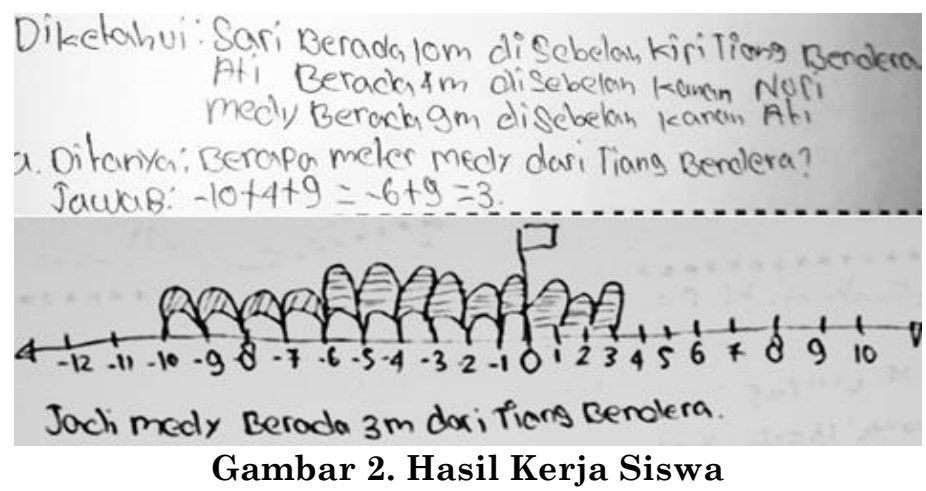

Gambar 2 memperlihatkan siswa menyelesaikan permasalahan dengan lebih dari satu cara. Penggunaan garis bilangan melalui representasi matematis yang diperlihatkan menunjukan siswa kreatif dalam menentukan letak posisi tiang bendera dan menggambarnya. Dalam menghitung posisi dari soal yang diujikan siswa menggunakan gambar bervariasi dan menarik yang dapat memberikan makna, sehingga dengan memperhatikan gambar tersebut siswa dapat mencari solusi penyelesaian dengan baik dan benar.

\section{Pembahasan}

Kreaktivitas penting untuk dimiliki siswa dalam mengkonstruksi berbagai ide-ide kreatif dalam pembelajaran matematika. Untuk meningkatkan kreaktivitas maka siswa perlu dilatih menyelesaikan soal-soal matematika yang menantang sehingga memicu kognitif siswa untuk mengeksplorasi berbagai ide kreatif.

Tujuan penelitian ini adalah menganalisis pengaruh metode D\&P terhadap peningkatan kreaktivitas matematis ditinjau dari KAM siswa. Hasil penelitian menunjukan terdapat pengaruh metode D\&P terhadap peningkatan kreaktivitas matematis siswa. Pengaruh peningkatan dikarenakan efektifnya penggunaan metode D\&P, karena metode D\&P dapat memfasilitasi siswa dalam latihan soal secara cepat dan melakukan praktek terhadap konsep yang dipelajari melalui bantuan modul pembelajaran. Hsu \& Maan Sheu (2008) menjelaskan bahwa metode D\&P dilakukan dengan cara memberikan latihan berulang dengan pemberian umpan balik dan materi disajikan dengan cepat.

Pengujian Post hoc test sebagai uji lanjut mengindikasikan kemampuan berpikir kreatif matematis siswa KAM tinggi dan sedang memiliki tingkat kreaktivitas yang tidak berbeda secara statistik sedangkan KAM tinggi $><$ rendah dan sedang $><$ rendah memiliki tingkat kemampuan berpikir kreatif yang berbeda. Siswa dengan KAM yang baik apabila dilatih secara kontinu maka kreaktivitasnya semakin lebih baik lagi.

Hal ini teridentifikasi melalui capaian persentase peningkatan kreaktivitas siswa pada berbagai level KAM. Siswa KAM rendah mencapai peningkatan 50\%, KAM 
sedang 59\%, dan KAM tinggi 67\%. Ketiga level kemampuan meningkat dalam kategori sedang. Kemampuan awal berkorelasi dengan ketercapaian hasil belajar, oleh karena itu kemampuan awal penting bagi siswa dalam pembelajaran. Henderson (2007) membangun hubungan antara pengetahuan awal siswa dan konsep-konsep baru yang akan dia pelajari adalah kegiatan pembelajaran yang penting.

Terkait dengan capaian tingkat kreaktivitas siswa, teridentifikasi 18,18\% siswa memiliki kreaktivitas dalam kategori sangat kreatif, dimana siswa mampu menunjukan kefasihan, fleksibilitas, dan kebaruan atau kebaruan dan fleksibilitas dalam pemecahan masalah terkait dengan operasi hitung bilangan bulat. 54,55\% berada pada kategori kreatif, dimana siswa mampu menunjukan kefasihan dan kebaruan atau kefasihan dan fleksibilitas dalam pemecahan masalah, dan 22,72\% cukup kreatif, serta 4,55\% memiliki tingkat kreaktivitas kurang kreatif, karena siswa hanya mampu menunjukan kefasihan dalam pemecahan masalah.

Analisis nilai $\mathrm{N}$-gain pada Gambar 1 memperlihatkan bahwa secara keseluruhan kelas, kemampuan berpikir kreatif matematis siswa mencapai peningkatan dalam kategori sedang. Peningkatan kemampuan berpikir kreatif dikarenakan siswa berlatih menyelesaikan permasalahan matematika yang menantang sehingga kemampuan berpikir kreatif siswa dapat dieksplorasi melalui pemberian latihan soalsoal non rutin bercirikan pola kemampuan berpikir kreatif. Balka (1974; Mann, 2006) kriteria untuk mengukur kemampuan matematika kreatif ditandai dengan penentukan pola pikir yang mengacu pada pemikiran matematika divergen. Putri dkk (2016) kemampuan berpikir divergen harus dikembangkan untuk menjadikan siswa yang kreatif, dimana kemampuan berpikir divergen harus dikembangkan sejak sekolah dasar. Hal ini dapat meningkatkan indikator-indikator kemampuan berpikir kreatif matematis siswa.

Hasil kerja siswa yang ditunjukan pada Gambar 2 memperlihatkan siswa menyelesaikan soal dengan berbagai cara, dalam hal ini terkait dengan aspek fleksibilitas dan difasilitasi dengan metode D\&P dalam mengeksplorasi ide-ide kreatif siswa. Worthington (2006; Mahmudi, 2010) mengukur kemampuan berpikir kreatif siswa dapat dilakukan dengan cara mengeksplorasi hasil kerja siswa yang merepresentasikan proses berpikir kreatifnya. Simonton (2014; Sharma, 2017) tiga perspektif utama dalam kreaktivitas: 1) proses yang menghasilkan ide kreatif; 2) orang berpikir dan memberikan ide kreatif; dan 3) produk yang mewakili atau mengkomunikasikan ide kreatif.

\section{Simpulan}

Berdasarkan hasil-hasil penelitian yang diperoleh, maka dapat disimpulkan beberapa hal sebagai berikut: 1) terdapat pengaruh metode D\&P terhadap peningkatan kemampuan berpikir kreatif matematis siswa kelas V SD Inpres 48 Ambon; 2) berdasarkan KAM kemampuan berpikir level tinggi dan sedang tidak ada perbedaan. Untuk level tinggi dan rendah, serta sedang dan rendah terdapat perbedaan dan ; 3) KAM level rendah, sedang, dan tinggi mencapai peningkatan kemampuan berpikir kreatif dalam kategori sedang. Hal ini dikarenakan metode D\&P efektif meningkatkan kemampuan berpikir kreatif siswa V SD Inpres 48 Ambon

\section{Saran}

Mengacu pada simpulan yang dihasilkan dari temuan penelitian maka dapat disarankan perlu dilakukan penelitian lanjutan terkait dengan implementasi metode Drill \& Practice dalam mengukur kemampuan matematis lainnya. Metode D\&P juga dapat diterapkan oleh guru dengan bantuan media pembelajaran kreatif dan dilakukan melalui proses latihan yang terstruktur baik secara individu mapun 
berkolaborasi sehingga siswa Sekolah Dasar dapat menguasai materi pelajaran matematika lainnya dengan baik.

\section{Referensi}

Alessi, S. M., \& Trollip, S. R. (1991). Computer based instruction: methods and development. Upper Saddle River, New Jersey: Prentice Hall.

Amabile, T. M. (1996). Creativity in context. Boulder, CO: Westview

Balka, D. S. (1974). Creative ability in mathematics. - In: Arithmetic Teacher 21, p. 633-636

Drowns, B., \& Robert, L. (1985). Journal of Computer-Based Instruction, 12(3), pp 5968

Ericsson, K. A. (2016). Summing up hours of any type of practice versus identifying optimal practice activities: Commentary on Macnamara, Moreau, \& Hambrick (2016). Perspectives on Psychological Science, 11, 351-354. doi:10.1177/1745691616635600.

Firdausi, Y. N., Asikin, M., Wuryanto. (2018). Analisis Kemampuan Berpikir Kreatif Siswa Ditinjau dari GayaBelajar pada Pembelajaran Model Eliciting Activities (MEA). Prisma Prosiding Seminar Matematika. https: //journal.unnes.ac.id/ sju/index.php /prisma/

Gajda, A., Karwowski, M., \& Beghetto, R.A. (2016). Creativity and Academic Achievement: A Meta-Analysis. Journal of Educational Psychology. Advance online publication. http://dx.doi.org/10.1037/edu0000133

Gee, Y. T., \& Umar, I. N. (2014). The Effects of Drill and Practice Courseware on Students' Achievement and Motivation in Learning English. International Journal of Educational and Pedagogical Sciences, 8(12), pp. 3812-3817.

Gregoire, J. (2016). Understanding Creativity in Mathematics for Improving Mathematical Education. Journal of Cognitive Education and Psychology, 15(1), 24-36

Hake, R, R. (1998). Interactive-engagement versus traditional methods: A sixthousand-student survey of mechanics tes data for introductory physics course. Am. J. Phys, 66 (1), 64-74.

Hailikari, T., Katajavuori, N., \& LindblomYlänne, S. (2008). The Relevance of prior knowledge in learning and instructional design. American journal of pharmaceutical education, 72(5), 113

Hana, N., \& Hamada, H. (2017). Creativity in the EFL Classroom: Exploring Teachers' Knowledge and Perceptions. Arab World English Journal (AWEJ), 8(4), 352-364

Henderson, K., L. (2007). The Effects Of Prior Knowledge Activation On Learner Retention Of New Concepts In Learning Objects. Doctoral Dissertation (Open Access), University of Central Florida. Online Tersedia: https://pdfs.semanticscholar.org/e1fc/ 5385da0f4f52536ba3051a6f60bb310d65c5.pdf

Hsu, L., \& Maan Sheu, C. (2008). A Study of Low English Proficiency Students' Attitude toward Online Learning. Electronic Journal of Foreign Language Teaching 5(2), pp. 240-264

Joong Kim, D., Chul Bae, S., Ho Choi, S., Jeong Kim, H., \& Lim, W. (2019). Creative Character Education in Mathematics for Prospective Teachers, Sustainability 11, 1730; doi:10.3390/su11061730

Kaufman, J. C., \& Beghetto, R. A. (2009). Beyond big and little: The four C model of creativity. Review of General Psychology, 13, 1-12. http:// dx.doi.org/10.1037/a0013688

Lehtinen, E., McMullen, J., Hannula-Sormunen, M.M., \& Gruber, H. (2017). Cultivating mathematical skills: from drill-and-practice to deliberate practice. The international Journal on mathematics education 49(7) $\cdot$ March 2017 with 2,857 Reads doi: 10.1007/s11858-017-0856-6 
Mahmudi, A. (2010). Mengukur Kemampuan Berpikir Kreatif Matematis. Makalah Disajikan Pada Konferensi Nasional Matematika XV UNIMA Manado. Online, (Tersedia):http://staffnew.uny.ac.id/upload/132240454/penelitian/Makalah+14+A $\mathrm{LI}+\mathrm{UNY}+$ Yogya+for+KNM+UNIMA+_Mengukur+Kemampuan+Berpikir+Kreati f+_.pdf, diakses 22-12-2019.

Mann, E. L. (2006). Creativity: The Essence of Mathematics. Journal for the Education of the Gifted. 30, (2), pp. 236-260.

Nadjafikhah, M., Yaftian, N., \& Bakhshalizadeh, S. (2012). Mathematical creativity: Some definitions and characteristics. Procedia-Social and Behavioral Sciences, 31, 285-29

Plucker, J., Beghetto, R. A., \& Dow, G. (2004). Why isn't creativity more important to educational psychologists? Potential, pitfalls, and future directions in creativity research. Educational Psychologist, 39, 83-96. http://dx.doi.org/ 10.1207/ s15326985ep3902_1

Purwaningrum, D., \& Sumardi. (2016). Efek strategi pembelajaran ditinjau dari kemampuan awal matematika terhadap hasil belajar matematika kelas XI IPS. Jurnal Managemen Pendidikan, 11(2), 155-167. Jurnal Elektronik Pembelajaran Matematika 2(2), $141-151$

Putri, A. R., Paidi., Subali, B. (2016). Divergent Thinking In Biology Science Process Skill Of Elementary School Students. Jurnal Pendidikan Biologi, 5(5), 39-50.

Razak, F. (2017). Relationship of initial capacity critical thinking ability in mathematics class VII SMP Boarding Immim Putri Minasatene. Jurnal Mosharafa, 6(1), 117-128

Runco, M.A.(1993).Creativity as an educational objective for disadvantaged students (RBDM 9306). Storrs: University of Connecticut, The National Research Center on the Gifted and Talented.

Sam Lim, C., Ngang Tang, K., \& Kee Kor, L. (2012). Drill and Practice in Learning (and Beyond). Encyclopedia of the Sciences of Learning, Springer Link, doi: https://doi.org/10.1007/978-1-4419-1428-6_706

Sharma. J. (2017). Effect Of Mathematics Learning On The Development Of Mathematics Creativity. International Journal of Research - Granthaalayah, 5(1), 151-158.

Silver, E. A. (1997). Fostering Creativity through Instruction Rich in Mathematical Problem Solving and Problem Posing. (Online) Tersedia: file:///C:/Users/PRODI\%20PGSD/ Downloads/97_3_Analyses Fostering Creativity throu.pdf, diakses (26-7-2019).

Simonton, D. K. (2012). Taking the US Patent Office creativity criteria seriously: A quantitative three-criterion definition and its implications. Creativity Research Journal, 24, 97-106.

Simonton, K. (2014). Genius, creativity and leadership. In T.Rickards, M.K.Runco and S.Moger (Ed), The Routledge companion to creativity (pp 247-255). Oxon, UK: Routledge.

Siswono, T . E. Y. (2008). Penjenjangan Kemampuan Berpikir Kreatif dan Identifikasi Tahap Berpikir Kreatif Siswa dalam Memecahkan dan Mengajukan Masalah Matematika. Jurnal Pendidikan Matematika "Mathedu" 3(1).

Sternberg, R., \& Lubart, T. (1999). The concept of creativity: Prospect and paradigm. In R. Sternberg (Ed.), Handbook of creativity (pp. 3-15). Cambridge, NY: Cambridge University Press

Takaria, J. (2018). Penerapan Pembelajaran Collaborative Problem Solving untuk Meningkatkan Self-Concept Mahasiswa. Jurnal Bimbingan dan Konseling Terapan, Vol 2(1); 83-93

Takaria, J., \& Talakua, M. (2018). The Ability Of Statistical Literacy Student Teacher Candidate In Terms Of Prior-Ability On Mathematics. Jurnal Kependidikan Penelitian Inovasi Pembelajaran, 2(2), 395-408

Torrance, E. P. (1966): The Torrance tests of creative thinking: Technical-norms manual. - Princeton, NJ: Personnel Press 
Takaria, J., Sahusiwa, Y.

Torrance, E. P. (1974): The Torrance tests of creative thinking: Technical-norms manual. Bensenville, IL: Scholastic Testing Services

Torrance, E. P. (1988): The nature of creativity as manifest in its testing. - In R. J. Sternberg (Ed.): The nature of creativity: Contemporary psychological perspectives. - New York: Cambridge University Press, p. 43-75

Vale, I., dan Barbosa, A. (2015). Mathematics Creativity in Elementary Teacher Training. Journal of the European Teacher Education Network Vol. 10, 101-109

Worthington, M. (2006). Creativity Meets Mathematics. [Online] Tersedia: http://www.childrens-mathematics.net/creativity_meets_mathematics.pdf. 